\title{
Philosophical view on the problem of degradation and regeneration as potential trends in interethnic communication culture
}

\author{
Tatiana N. Seregina - Alfiya R. Masalimova - Muhammet Usak - \\ Evgeniy M. Dorozhkin - Alexander A. Galushkin
}

DOI: 10.18355/XL.2019.12.02.15

\begin{abstract}
The authors introduce and discuss a theory that looks at a contemporary Russian society as a community rapidly losing skills necessary for successful cross-cultural communication which entails not only the ability to communicate in the international space, but also knowledge related to cultural characteristics, national traditions, customs and history of different nations that is essential in building a cognitive basis for developing respectful relations to other national cultures and their representatives. It is the knowledge and understanding of other nation's features and culture that forms the basis for developing the culture of interethnic dialogue. The purpose of the paper is to distinguish the factors that contributed to the destruction of the interethnic communication culture and tolerance crisis in the modern multiethnic space society. It is closely connected with a task of determining the conditions that could bring to the regeneration of interethnic communication as it is now considered the most important strategy for ensuring civilizational security. The polyphonic approach to study interethnic communication problems has been used as in a study to provide insights for the variable and subjective understanding of this phenomenon from the point of view of its integrity, versatility, variability, consistency, equivalence and equality of all the components of this phenomenon items. The authors have identified a number of factors that influence intensively the degradation process in interethnic communication. These factors include the destruction of a single international ideology, growth of national extremism, lack of effective national policy of the Russian state and the monoethnization in the national republics of Russia. The authors introduce their view on the principles of regeneration of the interethnic dialogue culture which imply the need for knowledge and understanding of traditions related to interethnic communication participants, understanding and improving relationships between ethnic groups, equality of the parties of communication, recognition of equal rights and obligations within the borders of the common civilization, a system of institutions involved in the reproduction process and ensuring its effectiveness.
\end{abstract}

Key words: regeneration of culture, the culture of interethnic communication, civilizational risks, intercultural communication, philosophical view

\section{Introduction}

One of the most problematic aspects in the system of social relations interethnic relations is associated with interethnic relations. They are full of conflicts, contradictions, prejudices, mistakes, resentments, but at the same time, they have a huge integrative potential for Russian society to be used in the construction of a new Russia, ensure the spiritual and material well-being of the Russian people and to overcome civilizational risks (Toynbee, 2009) threatening the very existence of Russia as a multinational and original civilization.

It is not the first time that this country is at the turning point of the history when consolidation and unity are needed to deliver a bright future to Russia, resist the insidious nationalism which has become the source of evil and greed (Zhdanov, 2012). According to Y.G. Volkov (2011) who linked implementation prospects of the opportunities to the process of developing a creative society, Russian society is a society of unrealized opportunities. Many of Russian citizens would agree to this, 
though understand that multinational population of Russia with all its ethnic diversity is capable of making a breakthrough.

One can hardly estimate the scale of a historical challenge that Russia is facing today. In fact, it is only possible to take into account the civilizational specifics of Russian society, the transformational peculiarities of its civilizational characteristics and make some sort of a high-accuracy prediction related to scenarios of its further civilizational development (Held, 1995).

However, the risk of a civilizational collapse of Russia induces an urgent need to find mechanisms to prevent this negative option after which the Russian civilization might become 'a thing of the past'. The basic civilizational characteristic of the Russian civilization as a civilization developing at the crossroads of Europe, the Middle East and Central Asia is the multi-ethnic character of its population. This feature is the basis of cultural diversity and cultural identity of Russia, but in the conditions of ethnic disintegration and conflict, it also becomes a source of civilizational security risks and, hence, implies the need for a deep socio-philosophical study of interethnic communication as an important aspect of Russian civilization. Historical patterns of development allow to predict the potential for regeneration of interethnic communication culture in the new civilizational reality of the country and under the conditions of developing a new civilizational identity of Russians.

The phenomenon of interethnic communication culture is not something new, it is an essential feature of Soviet society. Before we develop our ideas about the regeneration of interethnic communication culture in modern Russia, it is necessary to identify culture destruction factors related to interethnic communication in this country in order to objectively present a strategy used to build and maintain the culture of interethnic communication.

\section{Literature Review}

The interdisciplinary nature of the phenomenon would enable a polyphonic approach to study the problems of interethnic communication and variable-subjective understanding of this phenomenon in terms of its integrity, versatility, variability, consistency, equivalence and equality of all the components of this phenomenon items.

Solving the problem of civilizational security of Russia is connected with the theory of world-systems and their security (Braudel, 2008) with all its diversity (the theory of spiritual, demographic, political, national, cultural, national security) and emphasis on the theory of civilizational security (Aksit, 2006; Velieva et al., 2018). The ideas related to the topic and proposed in the works of Russian scientists have also been used to prove it (Yakovenko, 2006; Akhiezer, 1997; Paltsev, 2012).

The concept of civilizational identity has been also used (Lipkin, 2009) in interpreting a civilizational community from the point of view of its central meaning (ideals and higher values) forming a so-called "semantic core" which is incommensurable. The last feature creates difficulties in understanding of culture and life of one civilization by another despite the fact that there is a problem-free understanding between the members of the both within the boundaries of this civilization. This is what makes the foundation for introducing innovations, the spread of technological, ideological, political values and ideas, as well as interethnic communication culture. In other words, interethnic communication culture is based on common civilizational values and meanings (Greber, 2018), and identification of them is the main task to deal with when solving the problem of successful regeneration of interethnic communication culture.

In our concept, the culture of interethnic communication is an important mechanism for creating a new civilizational identity of Russians on the basis of civilizational, ethnocultural and civil attitudes of the community.

XLinguae, Volume 12 Issue 2, April 2018, ISSN 1337-8384, eISSN 2453-711X 
To discuss this concept, we need to disclose what "civilizational identity" means, as it is a central notion. Here we will start from the interpretation of civilizational identity concept proposed by A. Lipkin (2009), a Russian philosopher, who uses the concept of national community for its operationalization. Civilizational community, according to his view, has a civilizational spiritual core (which determines the meaning of life and its highest values) and sub-civilizational spiritual systems which are close to the common civilizational matrix, compared to the national community with its national culture.

A. Lipkin (2009) proposes to take into consideration existing central/core meanings (ideals and the highest values) forming a so-called "semantic core", which is incommensurable and creates difficulties in understanding of a certain civilization's culture and life by another civilization. Within the boundaries of the civilization there is a quick and easy mutual understanding between its members (representatives of different nations), and this is what is important when introducing innovations, encouraging technological, ideological, political values and ideas (Lipkin, 2009).

Since the basic semantic kernels are not subject to time and impacted by new elements in the process of socio-cultural transformation, they are prone to restoring and determining the essence and specifics of the functioning of civilization. In addition, this condition fits into the methodological framework of neo-institutional theory, in particular, the theory of institutional matrices (Kirdina, 2000), and we can argue that, having passed through the transformation process, the culture of interethnic communication acquires a new content and is regenerated under the conditions of interethnic relations (Taylor, 1992). However, the effectiveness of this process in modern Russian civilization will depend on the extent of success and completeness of the modernization process.

Laws of social regeneration (Zinoviev, 2007), civilizational development (Lipkin, 2009) and functioning of institutional matrices (Kirdina, 2000) facilitate the process of drawing a conclusion that restoration of the positive potential of interethnic communication culture in Russia may be considered as a true probability and should be based on historical cultural material, i.e. the experience of interethnic communication formed on the basis of the civilization spiritual core which determines the meaning of life and the highest values in society and provides unhindered understanding between its members within the boundaries of Russian civilization.

\section{Results and Discussion}

The peculiarity of the current situation can be characterized by the nations' focus on their own culture rather than broaden the outlook at the expense of information about other nations living in the same country. Therefore, the very socio-cultural basis of interethnic communication is being destroyed and the culture of interethnic communication is being intensively destructed under the influence of a number of factors:

- destruction of a single international ideology, i.e. "Friendship of Peoples" policy in the Soviet Union, that contributed greatly to the collapse of the system of international socialization when young people respected international values and national traditions and characteristics of each nation in the union;

- destruction of the Soviet identity that ensured every individual to belong to a single whole, regardless of their national specifics, and maintain national feelings and attitudes of a national group or ethnic group;

- growth of national extremism and terrorism affecting the image of the peoples in the most negative way, some representatives of them implementing extremist practices (especially distinctive in this respect are radical Islamists whose terrorist activities discredit the image of Muslim peoples, forms a negative attitude towards them as well as generates internal ethnic contradictions); 
- lack of effective national policy in the Russian state that caused the so-called national question in the country to be open;

- monoethnization of the national republics of Russia that caused reduction of interethnic interaction and limiting it to intraethnic contacts, loss of skills for interethnic communication and decrease in the number of interethnic marriages (in the regions with a high level of mixed ethnicity marriages they were a source of intercultural impact and ensured strong interethnic relations);

- the spread of ethnocentrism ideology in national regions of the Russian Federation accompanied with a collapse of internationalist ideology and growth of ethnoregionalist one.

Many Russian researchers have pointed out that there is a decrease in tolerance and culture of interethnic communication on the territory of modern multinational Russia (Vereshchagin, 2009; Gafurov, Khaydarov, Makhmutov, 2010; Fedyunina, 2012; Yarskaya, 2012). 'Multinational' means a territory where different nations coexisted and interacted with varying degrees of effectiveness for centuries, and eventually contributed to the formation of a strong multi-ethnic Russian state.

Today, the positive culture experience of interethnic communication in Russia has been destructed. This is evident due to such phenomena taking place as the growth of aggression, ill-will, cruelty, indifference, irritation and cultural alienation in relations between the different peoples of our country. A conflict version of the country development, in our opinion, is proof that some sort of anti-culture is being created here and threatening the civilizational security of the Russian state.

We can provide data to confirm this position, however, we'd like to note that the situation in the field of actual interethnic relations and their perception in Russia is very contradictory.

On the one hand, the growth of nationalism in Russia has been recorded and this is manifested in the fact that the majority of Russians, as shown by a survey of the Levada Center, advocate for residence restriction for people belonging to a number of nations (Russians on migration and ethnic tension, 2018). Only $11 \%$ of respondents, 2013, believed that "there should not be imposed any restriction on the residence of any nations" in Russia.

However, on the other hand, according to the results of the study carried out by Institute of Sociology of Russian Academy of Sciences (RAS), 47\% of Russians are convinced that Russia is a common home for many peoples and they influence each other; all peoples should have equal rights, no one should have any advantages (Analytical report, RAS). However, it should be also added that $31 \%$ of the respondents believe that Russians, making up the majority of the country's population, should have more rights, and this indicates nationalist tendencies in Russia. Scientists think is that despite the prevailing opinion that Russia is a common home for many peoples (nations) is gradually getting less and less support (Analytical report, RAS); this is evidenced by the abovementioned data: in 1995, the number of supporters of this point of view decreased from $65 \%$ to $47 \%$ which is very significant for a large country, especially given the fact that the number of those who adhere to the position that, though Russia is a multinational country, the Russians, making up the majority, should have more rights because they bear the main responsibility for the fate of the people on the whole, has doubled.

In general, according to the authoritative opinion of a Russian academician M.K. Gorshkov (2011), the development of events in a negative scenario is possible, because we should take into account that aggressive feelings and their localization are growing, and they are associated with real and serious "sons-of-the-soil" conflicts quite real in some regions of Russia.

XLinguae, Volume 12 Issue 2, April 2018, ISSN 1337-8384, eISSN 2453-711X 
This position may be supported by another study of the Institute of Sociology of the Russian Academy of Sciences, "Twenty years of reforms through the eyes of Russians" (2011). Its findings indicate a quite strong hostile attitude of Russians to certain ethnic groups. The reason for this, as the study showed, is that "people of a different culture behave as if they own this land", i.e. are 'sons-of-the-soil' here (63\%); 39\% believe that the cause of interethnic hostility is directly connected with "differences in people's behavior, their way of living" (Analytical report, RAS).

A major conclusion made as a result of the study conducted by RAS is that the twenty years that the country had lived in the post-Soviet reality after the collapse of the USSR revealed a high level of interethnic conflict; the situation in the field of interethnic communication had not changed for the better, i.e. we can hardly talk about the readiness of nations to communicate with representatives of other nationalities in Russia (Analytical report, RAS).

But we want to draw a reader's attention to balancing of opinions and positions of Russians on the issue of national and interethnic relations in the country; this reflects, on the one hand, the growth of nationalist trends, and on the other, a very positive attitude to the multinational population of Russia, as it is evidenced by the results of the survey of is RAS according to which one of the main ideas that can unite Russia is the idea of the nations united to solve global problems (Gorshkov, 2011) threatening humanity, and, presumably, first of all, Russia.

More than twenty years have passed since the collapse of the USSR, and many peoples of Russia still have been perceiving this phenomenon as a disaster (Gorshkov, 2011). As the research shows, the scanty part of Russian citizens considers the collapse of the USSR as a positive phenomenon. Therefore, nostalgic sentiments are still hovering in Russian society and, moreover, increase with the preservation of crisis factors in the functioning of the new Russian state and the growth of risk factors in the social development of the country.

The culture of interethnic communication is a process conditioned by the entire historical development of interethnic relations in society (Huntington, 2015). In this regard, it is not necessary to treat certain historical events and facts scornfully, especially if they are negative, since the history of the people displays historical moments associated with interethnic communication and forms their own perception of another nation endowed with specific features, properties, characteristics.

The history of interethnic relations with their positive and negative moments is remembered for a long time passing down from generation to generation (Gegel, Frolova, 2007). It is natural to remember inter-ethnic conflicts full of negativity related to the period of Perestroika and the collapse of the USSR. The most acute conflicts on national grounds seem to have been left behind but empirical data show that there has been a new surge in ethnic tension and deterioration in inter-ethnic relations in recent years; they may be caused by an increase in national extremist activity and terrorism in some regions of the country.

Today, Russia seems not to know where to go, which direction and idea to choose, and for what purpose. This is clearly evidenced by the strategy of the revival of archaic elements belonging to Russian history and the attempt of their "implantation" in the social fabric of modern society (for example, the revival of the Russian nobility, Cossacks, as well as certain symbols, ideology and ritualism).

In other words, A.A. Zinoviev (2007) was right when he claimed that Russia appeared to retreat two steps back in its development; in fact, to make the leap forward but failed because the path, or track, chosen did not correspond to its historical trajectory and logic of development, as well as civilizational specifics and institutional nature.

A.A. Zinoviev (2007), a Russian philosopher and writer, interpreted the modern Russian society as a sort of mutation (a hybrid) formed on the ruins of the Soviets, the reanimation of the pre-revolutionary feudalism and borrowed elements of Westernism, called the post-Soviet (Zinoviev, 2007). 
Reanimation of Russia based on Russia's Soviet and pre-Soviet past experience had practically to no effect, is no longer relevant. Moreover, it hinders Russia's progressive development forward. But there is something urgent that really needs to be restored: within the framework of the social regeneration law, the culture of interethnic communication has a chance for its reinstitutionalization in new conditions and different principles of developing the interethnic relations.

With regard to the culture of interethnic communication that was destroyed during the period of the collapse of international ideology accompanying the dissolution of the USSR, the social regeneration law can be considered as a positive phenomenon since the restoration of the culture of interethnic communication is a vital condition for the functioning of Russian civilization. However, as far as the transmitters of the Soviet interethnic communication are still alive, there is a chance to revive its value and pass on the basic foundations of the culture of "friendship of peoples" to new post-Soviet generations which proved (in our opinion) to be hardly dependent on national policy officially pursued in the country and on its doctrinal provisions. Currently, there is no better way to unite a multi-national Russian society than "friendship of peoples" idea about a tolerant and friendly attitude to the cultures of all nations.

Overcoming of imitation tendencies in the development of social, political, educational, cultural, economic spheres of Russian society is an essential condition for success in interethnic communication regeneration. Unfortunately, imitation technologies, having become the kind of a synonym for Russian modernization, testify to functional incapacity and destructiveness of the existing government incapable of realizing and implementing civilizational and identification intentions of Russia as they let it develop just on the basis of historical inertia within the community of the peoples inhabiting the country.

All other conditions for regeneration of the culture of interethnic communication (formation of a single state ideology in the framework of the spiritual nature of Russian civilization; countering national extremism; promoting patriotism, especially among the youth, etc.) cannot be provided outside delimitation process, otherwise, in the near future, Russian civilization itself may become a historical simulation.

Only the culture of dialogue between peoples can become the basis to build the culture of interethnic communication and a new, stable and effective civilizational identity (Orekhovskaya et al, 2017). The following basic principles of interethnic dialogue may be distinguished:

- awareness, knowledge and understanding of traditions, cultural characteristics of the nation that is a partner in the current cross-cultural communication;

- respect for traditions, culture, national achievements and national dignity of other ethnics;

- equality of the parties of interethnic communication with recognition of equal rights and obligations within the borders of a single civilization (Andrews et al., 2017), a single state and society;

- the high value of interethnic communication forming a request for interethnic contacts and responsible for a positive background in their implementation;

- a system of institutions involved in the development of regeneration of interethnic communication culture and their efficiency (family education, interethnic education, effective national policy, the ideology).

\section{Conclusion}

The authors hold to a stance that notwithstanding the conflict potential in interethnic relations mainly caused by the growth of terrorist activity of extremist forces, there is still a strong attitude in Russia to consider tolerance as an important factor in establishing peace in society. But, unfortunately, the attitude appeared to have a

XLinguae, Volume 12 Issue 2, April 2018, ISSN 1337-8384, eISSN 2453-711X 
tendency to reduce, that is why it is important for today's Russia not to miss the historical chance to stop the process of degradation in interethnic relations and take advantage of applying the supported positive attitude to inter-ethnic communication' significance to enhance inter-ethnic community dialogue and collaboration.

It is evident that Russia needs a new civilizational identification system that is able to cover the highest civilizational values, do not diminish the dignity and importance of particular nations' values. Such values include patriotism, paternalism, spirituality, irrationality as the basic values in the civilizational matrix of Russian society which have always set the direction and specific character to the development process in this country.

\section{Acknowledgments}

1. The work is performed according to the Russian Government Program of Competitive Growth of Kazan Federal University.

2. The publication has been prepared with the support of the "RUDN University Program 5-100".

\section{Bibliographic references}

AKHIEZER, A.S. 1997. Russia: criticism of historical experience. Novosibirsk: Sib. Chronograph. ISBN 5-87550-040-9

AKSIT, B. 2006. Globalization. Culture and Civilization: A Theoretical Framework for Comparative Sociological Research, Globalization and Turkish Civilization Symposium Papers. In: Scientific Journal Facta Universitatis, Series: Mechanical Engineering, pp. 136-142. ISSN: 0354-2025

ANDREWS, B. - WATSON, P.J. - CHEN, Z.J. - MORRIS, R.J. 2017. Postmodernism, positive psychology and post-traumatic growth within a Christian ideological surround. In: Journal of Positive Psychology, vol. 12, issue 5, pp. 489-500. ISSN: 1743-9760E-ISSN: 1743-9779

BRAUDEL, F. 2008. Grammar of Civilizations. Moscow: Whole world. ISBN 978-57777-0403-0

FEDYUNINA, S.M. 2012. Interethnic social and cultural relations and processes in modern multicultural society. In: Authority, issue 3, pp. 34-38. ISSN: 2071-5358

GAFUROV, I.Z. - KHAYDAROV, R.R. - MAKHMUTOV, Ch.N. 2010. Interethnic and interfaith tolerance in the local community. In: Authority, issue 7, pp.74-76. ISSN: 2071-5358

GORSHKOV, M.K. 2011. Russia: Twenty years later (some aspects of sociological analysis of society reform). In: Authority, issue 12, pp.11-22. ISSN: 2071-5358

GREBER, C. 2018. Postmodernism and beyond in occupational therapy. In: Australian Occupational Therapy Journal, vol. 65, issue 1 pp. 69-72. ISSN: 00450766

GEGEL, L.A. - FROLOVA, Yu.S. 2007. Multinational South-Russian region: religious card. In: Sociological research, issue 2, pp. 117-120. ISSN: 0132-1625

HELD, D. 1995. Democracy and the Global Order: From the Modern State to Cosmopolitan Governance. Stanford: Stanford University Press. Cloth ISBN: 9780804726863; Paper ISBN: 978080472687

HUNTINGTON, S. 2015. The clash of civilizations. Moscow: AST. ISBN 978-5-17085844-6

KIRDINA, S.G. 2001. Institutional matrices and development of Russia. In: Sociological journal, issue 1, pp.140-144. ISSN: 1562-2495

LIPKIN, A. 2009. Some problems of civilizational and national identity. Moscow: publishing House: Institute of scientific information on social sciences of RAS, pp. 146-156. ISBN: 978-5-248-00509-3 
OREKHOVSKAYA, N.A. - TYURIKOV, A.G. - RAZOV, P.V. - KIBAKIN, M.V. - KISELEVA, N.I. 2017. Student Youth Tolerance as a Factor of Socio-Cultural Integration. In: Eurasian Journal of Analytical Chemistry, vol. 129, issue7, pp. 12831289. ISSN: 1306-3057

PALTSEV, A.I. 2012. On the issue of methodological relevance of categories of national security. In: Authority, issue 1, pp.120-121. ISSN: 2071-5358

RUSSIANS ON MIGRATION AND ETHNIC TENSION. 2018. Available online: http://www.levada.ru/05-11-2013/rossiyane-o-migratsii-i-mezhnatsionalnoinapryazhennosti

TAYLOR, CH. 1992. Multiculturalism and the "Politics of Recognition". Princeton: Princeton University. ISBN 0-691-03779-5 (PA)

TOYNBEE, A.J. 2009 A Study of History: the genesis, growth and disintegration of civilizations. Moscow: AST. ISBN 978-5-17-057736-1

TWENTY YEARS OF REFORMS THROUGH THE EYES OF RUSSIANS. 2011. Analytical report. Polis. In: Political research, issue 6, pp. 109-119. ISSN: 1026-9487 VELIEVA, S.V. - MASHKIN, N.A. - KHAIRULLINA, E.R. - SEMENOVA, T.N. - VARLAMOVA, M.E. - GUSEVA, T.S. - DOLGASHEVA, M.V. 2018. University student professional selfactualization: Context of personality subjectivity. In: Espacios, vol. 39, issue 20, article number 12. ISSN: 0798-1015.

VERESHCHAGIN, A.V. 2009. Transformation of the family institute and demographic processes in modern Russia. Rostov-on-Don: Publishing house of SFU. ISBN 978-5-9275-0566-1

VOLKOV, Y.G. 2011. Creative society as a goal of Russian modernization. In: Sociological research, issue 11, pp. 25-32. ISSN: 0132-1625

YAKOVENKO, I.G. 2006. Risks of social transformation of Russian society: cultural aspect. Moscow: Progress Is A Tradition. ISBN: 5-89826-258-X

YARSKAYA, V.N. 2012. My tongue is my enemy: Racist discourse in Russian society. In: Sociological research, issue 6, pp.46-53. ISSN: 0132-1625

ZHDANOV, YU.A. 2012. In the name of humanism and unity of Russia. In: Humanities of the South of Russia, issue 1, pp. 19-22. ISSN: 2227-8656

ZINOVIEV, A.A. 2007. Postsovetizm: public lecture. Available online: http://vybory.org/articles/480.html

Words: 4393

Characters: 30255 (16,81 standard pages)

Assoc. Prof. Tatiana N. Seregina, $\mathrm{PhD}$

Department of Sociology, History and Philosophy,

Financial University under the Government of the Russian Federation

49 Leningradsky Avenue

125993 Moscow

Russia

sereginatatiana@gmail.com

Prof. Alfiya R. Masalimova, Doctor of Education

Institute of Psychology and Education,

Kazan (Volga region) Federal University,

18 Kremlyovskaya Str.

420008, Kazan,

Russia

alfkazan@mail.ru

XLinguae, Volume 12 Issue 2, April 2018, ISSN 1337-8384, eISSN 2453-711X 
Prof. Muhammet Usak, PhD

Institute of Psychology and Education,

Kazan (Volga region) Federal University,

18 Kremlyovskaya Str.

420008, Kazan,

Russia

musaktr@gmail.com

Prof. Evgeniy M. Dorozhkin, Doctor of Education.

Russian State Vocational Pedagogical University

11 Mashinostroitelej Str.

620098 Yekaterinburg

Russia

evgeniy.dorozhkin@rsvpu.ru

Prof. Alexander A. Galushkin, $\mathrm{PhD}$

Assoc. Prof. on International Laver

Director of the Scientific and Educational Center "Legal Research"

Peoples' Friendship University of Russia (RUDN University)

Miklukho-Maklaya Str. 6

117198, Moscow

Russia

Head of the Laboratory of Economics and National Economy Management Stolypin International Institute of Informatization and Public Administration 11/2 Malaya Semyonovskaya Str.

107023, Moscow

Russia

alexander.galushkin@yandex.ru 